logos_i_ethos_2021_2_(58), s. 35-53

https://doi.org/10.15633/lie.4168

Wojciech Wojtyła

https://orcid.org/0000-0002-5482-705X

University of Technology and Humanities in Radom

\title{
Personalist Foundations of the Constitutional Principle of the Dignity of Human Person
}

In the Constitution of the Republic of Poland dated 2 April 1997, human dignity is treated as a fundamental value of the legal order. Its preamble reads: "We call on who-
Wojciech Wojtyła, Doctor of Humanities in the field of Philosophy, Assistant Professor at the Chair of Theory, History and Philosophy of Law, University of Technology and Humanities in Radom. ever shall apply this Constitution for the good of the Third Republic of Poland to do so in care for preservation of the native human dignity, the right to freedom, and the duty of solidarity with others and treating respect for these principles as the immovable foundation of the Republic of Poland." Meanwhile, Article 30 stipulates: "The native and inalienable human dignity is the source of human and civic rights and freedoms. It is immovable and its respect and protection are duties of public authorities." The Polish constitution giver has permanently bound human rights and freedoms with human dignity, which is 'native' and 'inalienable.' This is neither the state, will of a sovereign nor law but the dignity which is the source of rights and freedoms under the Constitution. These rights and freedoms cannot be defined in an arbitrary fashion, even at the constitutional level, since they are conditioned by the human nature itself. ${ }^{1}$ Thus, dignity is the foundation of the entire legal system in the state and

1 Cf. P. Polak, J. Trzciński, Konstytucyjna zasada godności człowieka $w$ świetle orzecznictwa Trybunału Konstytucyjnego, "Gdańskie Studia Prawnicze” 40 (2018), p. 257. 
constitutes the value guiding interpretation and application of the Constitution. This function is known as the principle of human dignity. ${ }^{2}$ This means all its provisions should be interpreted in the spirit of respect for the native human dignity. ${ }^{3}$ It also denotes acceptance of the personalist orientation in many areas of state policy. ${ }^{4}$

Although human dignity is accepted as the basic anthropological category of contemporary legal systems, it has not been defined in a normative act of either international, EU or national laws. ${ }^{5}$ This paper is an attempt at answering the question, what reality is the person's dignity from the viewpoint of personalism and what constitutes it, and then demonstrating the dignity is not only an objective criterion of moral good and evil but also a universal criterion of the good state. The notion of human dignity is a philosophical category, therefore, its explication belongs in the domain not of the legal doctrine but of philosophy. Among a range of dignity theories, the proposal derived from the conviction, crucial to personalism, that each man deserves particular respect due to being a person is inspirational in a number of ways.

Given the multiple profiles and natures of personalism, it should be added the issue of human dignity will be discussed here in the terms developed by Neo-Thomist personalism in its metaphysical, axiological, and ethical profiles and based primarily on achievements of Karol Wojtyła and his disciples. Beside a range of leading lights of the Polish personalism, I will refer to utterances of Robert Spaemann.

${ }^{2}$ Cf. S. Zieliński, Rozumienie godności człowieka i jej znaczenie w procesie stanowienia i stosowania prawa. Propozycja testu godności i regulacji prawnych z zasada godności człowieka, "Przegląd Sejmowy" 27 (2019) nr 4 (153), p. 107.

${ }^{3}$ Cf. S. Zieliński, Rozumienie godności człowieka, p. 108.

${ }^{4}$ Cf. J. Auleytner, Polityka społeczna. Teoria i praktyka, Warszawa 2000, p. 351.

5 Cf. J. Wroceński, Godność osoby ludzkiej podstawą prawa do wolności religijnej, "Prawo Kanoniczne" 59 (2016) nr 3, p. 8. 


\section{The starting point - every man is a person}

The theory of society, state, and ruling order is principally dependent on the way the question, who is man, is answered. Therefore, the concept of man that implies a theory of public life and its foundations is a key part of any philosophical current or school. Understanding of man's ontological structure is also a pre-requisite to understanding the fact of law, its binding force, and scope. ${ }^{6}$

The notion of the person and its dignity has played a crucial role in the personalist anthropology and ethics. As Tadeusz Biesaga notes, contrary to 'the human nature,' it doesn't suffer from the reductionist, naturalist method of interpreting the human being, particularly in its corporeal dimension, that's why it has united thinkers from various philosophical trends and traditions. ${ }^{7}$ A number of elements have influenced development of the personalist vision of man. It was already Plato and Aristotle who contributed to highlighting the exceptionalism of human being in the world. The theory of hierarchical structure of reality and transcendence of the human soul are Plato's fundamental concepts. Addressing the question of soul, Plato pointed out man's intelligent, intangible, and indestructible dimension. He thereby oriented his discussion towards questions of man's genesis and destiny, as well as status in the structure of the world. ${ }^{8}$ The Platonic discovery led to the recognition man is elevated above the whole empirical world, radically distinct from other beings, with a dignity all of his own. ${ }^{9}$ Aristotle, in turn, noted man, essentially reasonable and endowed with potentials, needs others, i.e. appropriately organised communities, to develop. However, this public way of living doesn't rule out man's subjectivity. The Stagyra thinker lays emphasis on the unity, rationality, and potentiality of the human being,

6 Cf. M.A. Krąpiec, Człowiek i prawo naturalne, Lublin 1986, p. 127.

7 Cf. T. Biesaga, Podstawy etyki i bioetyki, Kraków 2016, pp. 358-359.

8 Cf. G. Reale, Historia filozofii starożytnej, t. 2: Platon i Arystoteles, tłum. E. Zieliński, Lublin 1996, pp. 227-228.

9 Cf. J.M. Bocheński, W obronie cywilizacji chrześcijańskiej, in: Polski testament. Ojczyzna, Europa, cywilizacja, Komorów 1999, p. 120. 
thus providing a major impulse to discovery of man's dignity-driven being and action. ${ }^{10}$

The discovery of the person's universe was a long historical process.

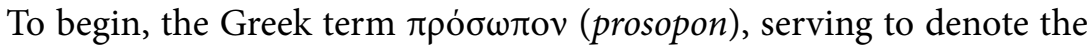
person, had meant a mask put on an actor's face in Greek theatre to reinforce the voice and represent the essence of a play, whose contents were expressed by means of the actor's words, gestures, and deeds. They all disclosed a certain truth about man. The mask stood for the whole quality of a character. In this way, the notion of mask brought closer the intuition of comprehending man in terms of person - an individual subject capable of conscious and autonomous actions. ${ }^{11}$ Since Cicero, the Latin word persona meant man's nature and role in Roman public life. It was incorporated into Roman legislation in the late $2^{\text {nd }}$ century $\mathrm{AD}$ to refer to a legal entity, an individual's dignity, and free citizen as distinct from a slave, considered a non persona or res. ${ }^{12}$

The philosophy of ancient Greece and Rome was supplemented with Christian thinking to give rise to an understanding of man beyond the general human interpretative horizon of his existence that has survived till the present. ${ }^{13}$ The ethics founded upon Christianity sees man not as an individual or a replica produced by divisions of matter, but as a person. This is because the notion of person and its dignity directly addresses man's subjectivity, exceptionalism, awareness, freedom, and thus the nascent world of values. ${ }^{14}$ "The person," R. Spaemann writes, "isn't a species-based concept but the way in which individuals of the man species exist. Each has a place of their own in the community of persons we refer to as humankind." ${ }^{15}$ There is an ontological difference between

10 Cf. P. Skrzydlewski, Kolektywizm, indywidualizm a osobowa wizja człowieka, in: Spór o osobę w świetle klasycznej koncepcji człowieka. Studia i rozprawy, Kraków 2012, pp. 164-165.

11 Cf. P. Skrzydlewski, Kolektywizm, indywidualizm, p. 165.

12 Cf. Cz. S. Bartnik, Personalizm, Lublin 2000, p. 70.

13 Cf. T. Biesaga, Podstawy etyki i bioetyki, p. 358; see also: G. Barth, Hermeneutyka osoby, Lublin 2013, p. 122.

14 Cf. T. Biesaga, Podstawy etyki i bioetyki, p. 358.

15 R. Spaemann, Osoby. O różnicy między czymś a kimś, tłum. J. Merecki, Warszawa 2001, p. 304. 
man, who always is somebody as a person, and beings that aren't persons. The difference consists in other ways of being. ${ }^{16}$

Several related definitions of person have evolved as part of the philosophical tradition that continue to serve as important points of reference. Boethius's (480-524) is the oldest and most universally accepted. In his Liber de persona, the Roman philosopher wrote: persona est naturae rationalis individua substantia (a person is the individual substance of the rational nature). ${ }^{17}$ Thomas Aquinas referred to that definition, stating persona est individuum subsistens in rationali natura (a person is an individual subsisting in the rational nature). ${ }^{18}$ In the Aquinas philosopher's view, no being comprises such a rich gamut of ontological perfections in such a profound unity as a person does. The personal existence is the most perfect form of being. The person itself, meanwhile, signifies what's the most perfect in nature: Persona significat id quo est perfectissimum in tota natura. ${ }^{19}$

The Aquinas philosopher's thought played a key role in development of the personalist vision of man. It became an intellectual platform for personalism as well. St. Thomas drew attention to the personal nature of man's being and acting which has its source in the soul, also the act of man's existence as man. The human soul is not only a form organising the mater of its particular body but also a form creating and organising the corporeal matter by endowing it with a definite, individual, and unique existence. ${ }^{20}$ Thomas's analysis shows the human person as a being that, existing in itself as a subject, expresses itself with reasonable and free acts. That self-expression always happens in matter and through matter. Man is a person since he possesses a unity and capacity

16 R. Spaemann, Osoby, p. 85.

17 A. Maryniarczyk, Realistyczna interpretacja rzeczywistości, Lublin 2005, p. 84 (Zeszyty z Metafizyki, 3).

18 V. Possenti, Osoba nowa zasada, tłum. J. Merecki, Lublin 2013, p. 29.

19 Tomasz z Akwinu, Suma teologiczna, I, q. 29, a. 3.

${ }^{20}$ Cf. E. Gilson, Tomizm. Wprowadzenie do filozofii św. Tomasza z Akwinu, tłum. J. Rybałt, Warszawa 1998, pp. $220 \mathrm{ff}$. 
for guiding himself by virtue of his rationality and freedom. ${ }^{21}$ Each man, being a person, constitutes a separate ontic individual who owes its being to its own act of existence. Karol Wojtyła employed the ancient formula persona est sui iuris to express the specific reality of the human being. It reflects not only the irreducible nature of the person, i.e. each separate human ' $I$,' but also indicates this is the very subjectivity of a person as someone irreducible by their very essence to being something that is the source of law. Although a person is an accidental being in the ontological sense, it is an absolute in the axiological dimension as it is eligible for unassailable dignity. ${ }^{22}$

Rank and degree of perfection of a person's entire reality are sources of their due respect. The recognition every man deserves a particular reverence for being a person is the foundation of personalist anthropology, for which biological membership of the humankind is the sole criterion of being a person. ${ }^{23}$

\section{Person, or the value above all other values}

Personalism advocates affirmation of man for no reasons or considerations other than for himself (persona est affirmanda propter se ipsam). ${ }^{24}$ Respect for the person's dignity is the ethical foundation of the state in the personalist concept of public life. It is the objective criterion of the good state whose acting structure is evaluated by whether and to what extent it provides man, defined as an individual person, with the means necessary for their individual development. In the personalist perspective, society develops only where persons forming it develop as optimally as possible. Dignity, as well as the common good, are among pre-constitutional values that aren't subject to the voting procedure, since not everything is decided by a majority in a democratic

21 Cf. Tomasz z Akwinu, Suma teologiczna, I, q. 76, art. 1, resp.

${ }^{22}$ Cf. A.M. Wierzbicki, Karola Wojtyty filozofia osoby ludzkiej jako podstawa obrony praw człowieka, in: Jan Paweł II. Posługa myślenia, red. J. Kupczak, D. Radziechowski, Kraków 2011, p. 146.

23 Cf. R. Spaemann, Osoby, p. 305.

${ }^{24}$ Cf. A. Szostek, Rola pojęcia godności w etyce, "Studia Filozoficzne" (1983) nr 8-9, p. 80. 
state. Therefore, discussions about the Constitution, the first act of state formation, should determine values that will organise the whole state in axiological terms and provide its foundations. ${ }^{25}$ This applies to the work on the Polish Constitution of 2 April 1997 . $^{26}$

A concept of man is the basis of statutory law. Personalists argue an adequate cognition of man involves primarily discovering the truth about their dignity. Recognition of the person's ontic and axiological rank among other beings entails the moral duty of affirming the person for themselves, specific to personalism. The notion of dignity, represented in the legal order, is interdisciplinary, though, which obstructs consensus regarding its meaning. It is the object of interest to philosophers, sociologists, psychologists, theologians, and others. In principle, two approaches to dignity can be distinguished. According to one (Maria Ossowska), dignity isn't a native value. Man acquires and may forfeit it. The other view (Adam Rodziński, Karol Wojtyła, Tadeusz Styczeń, Andrzej Szostek) asserts the person's dignity is an ontic, native, inalienable, and binding value. ${ }^{27}$

Ossowska distinguishes two varieties of meaning in the notion of dignity. "In line with the first," she writes, "there are some who have dignity and some who haven't." According to the other, all are eligible for dignity due to man's privileged status in nature. ${ }^{28}$ That author believes dignity in the latter sense is unloseable and ungradable. It is associated with the conviction man possesses special qualifications like an immortal soul, capacity for reasonable management of his conduct or for controlling his desires. In Ossowska's opinion, these features of humanity should rather be described as 'eminence,' a good equivalent of the Latin phrase dignitas

25 Cf. W. Chudy, Osoba ludzka w społeczeństwie, in: Katolicka nauka społeczna. Podstawowe zagadnienia $z$ życia społecznego i politycznego, Katowice 2007, p. 56.

${ }^{26}$ Cf. A. Zoll, Czy demokracja pomaga w stanowieniu prawego prawa?, in: Sacrum i kultura. Chrześcijańskie korzenie przyszłości, Lublin 15-17 IX 2000, red. R. Rubinkiewicz, S. Zięba, Lublin 2000, p. 67.

27 Cf. F. Mazurek, Godność osoby ludzkiej jako wartość absolutna, "Roczniki Nauk Społecznych" 21 (1993) nr 1, p. 266.

28 M. Ossowska, Normy moralne. Próba systematyzacji, Warszawa 1972, p. 52. 
humana. ${ }^{29}$ The dignity which is not deserved automatically, one should work for with their own deeds. The constitutional principle of human dignity doesn't apply to this type of the so-called personality dignity.

Rodziński attempts to order the semantic varieties of dignity. His distinction and making a connection between personal and personality dignities are worthy of attention. Rodziński writes: "Our human nature is the source of all our natural personality glory expressed in our culture and civilisation; this is its ontic status that decides that man, as a being endowed with the capacity for reasoning grounded in intellectual intuition, can, based on the rationality he is in a way condemned to, turn out to be reasonable, too, that is, to actuate another perfection to which he is no longer condemned but to which he is explicitly invited in his very nature."30 Rodziński claims "personal dignity as an ontic value of a specific being has no authentic pole (since there is no anti-being), whereas the personality value arising from affirmation of that same personal dignity in attitudes and conduct has just such a counterweight in its privative absence wherever the value should have occurred."31 Man, by virtue of his very nature in both the descriptive and axiological senses, is different from the rest of beings. As a person, he exceeds and is more precious than all other beings on Earth. This preciosity is defined as personal dignity. ${ }^{32}$ Rodziński asserts the ontic dignity of the human person is the sole criterion of natural morality. ${ }^{33}$ This dignity is native, permanent, lasting, and inalienable. It is up to a subject, meanwhile, to enhance or detract from personality dignity, since it is a result of acquiring certain moral capacities, or virtues. ${ }^{34}$

From the viewpoint of personalist ethics, what is important is that the human dignity, of unloseable value, 'calls for' double respect, both from others, and from a subject endowed with that dignity. This means

\footnotetext{
29 Cf. M. Ossowska, Normy moralne, pp. 52ff.

30 A. Rodziński, U podstaw kultury moralnej, Warszawa 1980, p. 83.

31 A. Rodziński, U podstaw kultury moralnej, p. 86.

2 Cf. A. Szostek, Rola pojęcia godności w etyce, p. 80.

33 Cf. A. Rodziński, U podstaw kultury moralnej, p. 92.

34 Cf. T. Biesaga, Podstawy etyki i bioetyki, p. 309.
} 
the fact of being a person 'calls for' living in accordance with what one is. Recognition of such dignity is expressed in the prohibition against treating yourself and others as means to attaining your own goals. Somewhat specifying Kant's second categorical imperative, K. Wojtyła has formulated the following personalist norm: "Whenever a person is an object of action in your conduct, remember you cannot treat them as means to an end, as instruments, but must take note they do or should have ends of their own." ${ }^{35}$ A person is a good "that cannot be treated as an object for use and as a means to an end." ${ }^{36}$ The positive side of this principle states "a person is such a good that only love is an adequate and fully valuable reference to them." ${ }^{37}$

A person's value is associated with their entire being. To emphasise the intrinsic value of a person, Wojtyła introduces a distinction between value of a person as such and values in a person. "Value of a person itself," he writes, "should be clearly distinguished from the various values subsisting in a person." ${ }^{38}$ Dignity is what shows a person is "the value of values. ${ }^{39}$ Wojtyła believes man has a special dignity by virtue of his personal existence. This dignity is ontic, therefore unloseable: neither a person itself can get rid of it, nor can anyone else deprive a person of it in any way. ${ }^{40}$ Incessant confrontation of a human being with the world of nature and technology leads to understanding of a person and their dignity. To recognise man's dignity is to place him above the natural world and everything arising from that world. All man's products are mere, though necessary means to self-fulfilment as a person, a rational and free being. ${ }^{41}$ The personalist norm proposed by Wojtyła has a social

35 K. Wojtyła, Miłość i odpowiedzialność, Lublin 2001, p. 30.

${ }^{36}$ K. Wojtyła, Miłość i odpowiedzialność, p. 42.

37 K. Wojtyła, Miłość i odpowiedzialność, p. 42.

38 K. Wojtyła, Miłość i odpowiedzialność, p. 109.

39 Cf. T. Biesaga, Godność a wolność w antropologii Karola Wojtyły, in: Ku rozumieniu godności człowieka, red. G. Hołub, P. Duchliński, Kraków 2008, p. 68.

40 Cf. A. Pala, Godność - wolność - miłość: struktura dynamizmu życia osobowego człowieka w ujęciu Karola Wojtyly, "Logos i Ethos" (2019) 2, p. 7.

${ }_{41}$ Cf. K. Wojtyła, Człowiek jest osoba, in: K. Wojtyła, “Osoba i czyn” oraz inne studia antropologiczne, red. T. Styczeń et al., Lublin 1994, p. 418. 
dimension. The person's dignity at its centre is a basic good not only of individual but also of collective life. ${ }^{42}$

Wojtyła's personalism is developed by Styczeń and Szostek. Analysis of the moral obligation as a normative interpersonal relation, the starting point of ethics for Styczeń, leads him to a cognitive discovery of personal dignity a subject-person discovers in themselves and in every other subject-person. In Styczeń's view, a person's dignity is given us directly, immediately, and intuitively in the experience of moral obligation. This is a subject-person's duty to affirm someone as an object-person due to their peculiar value. Personal dignity is implicitly co-given in contents of the experience of moral obligation. The very presence of an object-person in the field of a subject-person is enough for the obligation of the former's affirmation to come into existence and continue existing. ${ }^{43}$ This obligation is different in nature than the juridical obligation, which exists by force of an appropriate act of positive legislation. It also differs from the ethological obligation, substantiated and motivated by cultural factor, and from praxeological obligations, intended to gain individual or group benefits. ${ }^{44}$

Styczeń claims disrespect of human dignity undermines the most profound foundations of democracy, expected to rest on the principle of justice. He writes: "To govern the state is to serve, by means of law, each individual man and all people, without any exceptions, within the state's jurisdiction." ${ }^{45}$ Since man is what he is, that is, man, if he is alive, ${ }^{46}$ to secure somebody as man is first of all to secure their life. Therefore, respect for human dignity due to every man as the supreme good among the things and values of this visible world requires an absolute respect

42 Cf. K. Wojtyła, Człowiek jest osobą, p. 420.

${ }^{43}$ Cf. T. Styczeń, W sprawie etyki niezależnej, in: T. Styczeń, Wprowadzenie do etyki, Lublin 1993, p. 65.

${ }^{44}$ CF T. Styczeń, Filozoficzna koncepcja prawa naturalnego, "Analecta Cracoviensia" 1 (1969), pp. 300-301.

45 T. Styczeń, Nienarodzony miara demokracji, in: T. Styczeń, Wprowadzenie do etyki, p. 180.

${ }^{46}$ Cf. Arystoteles, O duszy II, 4: 415 b 13, in: Dzieła wszystkie, t. 3, tłum. P. Siwek, Warszawa 1992. 
for the right to life. A verbally declared respect for human dignity that wouldn't in practice comprise respect for each human life would be a fiction. ${ }^{47}$ Since the beginning and end of a person's existence cannot be separated from the beginning and end of human life, that respect applies both to life of a conceived, heavily handicapped, and terminally sick human. ${ }^{48}$

Sense of the concept of dignity is also explored by Szostek. He notes the native and inalienable personal dignity is a value that gives rise to and substantiates in a subject the specifically moral obligation of certain actions. Its recognition, though involved in cognition of any other human characteristics and assuming a degree of maturity in a subject etc., is the root cognition, a kind of experience. Szostek points out both everyday sensibility and a range of otherwise diverse thinkers like stoics, Kant, Kotarbiński or Rawls, accept the special value of each human person as something obvious. Although they express it with a variety of formulas, differing in their views about the ultimate foundation of that dignity, they agree in ascribing to man the very fact of a special preciosity that is binding upon others. ${ }^{49}$ Szostek asserts personal dignity is an object of not so much demonstration as showing. ${ }^{50} \mathrm{He}$ writes: "Indeed, it can be shown with parables ..., its connections with particular deeds can be proven ..., but a person's value itself, referred to as dignity by virtue of its exceptional status, cannot be demonstrated in any way other than by referring to its intrinsic obviousness, thus, not proving but showing it." ${ }^{\text {11 }}$ Personal dignity is particularly evident where it is under threat and opposes deeds unworthy of a human person. The conscience, witness of the truth of a human person's dignity, is its unique guardian. ${ }^{52}$ The analyses outlined above merit a separate and more in-depth consideration. They aren't intended to merely list a variety of views regarding

47 Cf. T. Styczeń, Nienarodzony miarą demokracji, p. 184.

48 Cf. T. Styczeń, Nienarodzony miara demokracji, pp. 175-188; R. Spaemann, Osoby, pp. $298 \mathrm{ff}$.

49 Cf. A. Szostek, Rola pojęcia godności w etyce, p. 83.

50 Cf. A. Szostek, Wolność - prawda - sumienie, "Ethos" 4 (1991) nr 3-4 (15-16), p. 32.

51 A. Szostek, Wolność - prawda - sumienie, p. 32.

52 Cf. A. Szostek, Wolność - prawda - sumienie, p. 29. 
personal dignity and are presented to show the human dignity, the starting point of personalism, is essentially related to humanity, to the very fact of being human. In the framework of personalist thinking, each human person deserves respect for their dignity (value, preciosity). The authors described above in a way jointly confirm the impossibility of capturing clearly what dignity is essentially. Its full and adequate discovery and expression remain as if beyond the reach of language and thought. Morally, therefore, dignity primarily manifests itself as a mystery and a unique challenge for men of good will.

\section{From the obligation to affirm person's dignity to the duty of solidarity with others}

The category of 'participation,' introduced to the language of social philosophy by Wojtyła, may be of interest to interpretation of the constitutional notion of human dignity. Wojtyła affords the concept, known from the philosophical tradition, a specific, deeper meaning than everyday associations with membership or taking part in joint undertakings. He understands participation as "what corresponds to the person's transcendence in action where the action is carried out with others in a variety of social or interpersonal relations. ${ }^{53}$ Using the concept of participation, Wojtyła identifies a specific property inherent in a person's subjective structure, "internal and homogeneous, which decides that, by being and acting jointly with others, a person is and acts as the person." ${ }^{44}$ This is "a property of the person itself, expressed in the ability to provide a personal (personalist) dimension to your own being and acting when man exists and acts together with others." ${ }^{35}$ The capacity for participation is a unique feature of a person that enables their subjective presence in a community.

53 K. Wojtyła, Osoba i czyn, in: K. Wojtyła, "Osoba i czyn” oraz inne studia antropologiczne, p. 309. Osoba i czyn was first published in Cracow in 1969. I refer to the $3^{\text {rd }}$ edition of 1994 here.

54 K. Wojtyła, Osoba i czyn, p. 310.

55 K. Wojtyła, Osoba: podmiot i wspólnota, in: K. Wojtyła, "Osoba i czyn" oraz inne studia antropologiczne, pp. 20-21. 
Wojtyła's analysis of participation cannot be cited in its entirety here. Two meanings he ascribes to this notion are important for the purposes of this paper. To participate is first to realise the common good with others and, second, to take part in another's humanity. The former sense emphasises the moment of a person's subjective presence among other persons while being and particularly acting jointly. Wojtyła writes: "The common good is not only a goal of action in a community defined in purely subjective terms, but also, and even above all, what conditions and somehow releases the participation in persons acting jointly, thereby forming in them a subjective community of action." ${ }^{56}$ The human person and its capacity for subjective commitment to any type of community it is present in is the most fundamental common good of each community. In this sense, the so-called 'human capital' is the common good. It encompasses the person's capacity for creative initiatives, their creativity, competences, and experience, that is, everything with which they can creatively serve their community. ${ }^{57}$

Wojtyła supplements this understanding of participation with one more dimension. Namely, he asserts the person's capacity for participation touches the level expressed with the notion of 'the neighbour.' Discovery of the neighbour in another, in whose humanity we participate, is the basis of the personalist imperative of affirming the person for itself. "Any participation in a community relies on it," he writes, "while finding its personal sense by means of the capacity for participating in humanity of each. This is what is indicated by the notion of neighbor." ${ }^{38}$ The capacity for participation in humanity itself is at the core of any participation, since any participation gains there both a personal depth and a universal nature that reaches even further than any otherness. Making the neighbour the key point of reference for community building helps

56 K. Wojtyła, Osoba i czyn, p. 321.

57 Cf. W. Wojtyła, Transcendencja i uczestnictwo jako klucz do zrozumienia osoby. Przyczynek do antropologii Karola Wojtyły-Jana Pawła II, “Ethos” 33 (2020) nr 1 (129), p. 376.

58 K. Wojtyła, Osoba i czyn, p. 331. 
to note and value in another what goes beyond their membership of any grouping or political party. ${ }^{59}$

Remarkably, the creators of the Polish Constitution call for respect for the native human dignity and right to freedom while reminding of the duty of solidarity with others. Solidarity is related to personalism and participation. It arises from the principle of dignity of the human person. In Wojtyła's opinion, the attitude of solidarity arises from the very human nature. This is the basic, authentic form of the person's participation in a community, of which it is the foundation. This conception of solidarity presumes an anthropology according to which man is self-fulfilled in relations with another, and a community is a constitutive dimension of the person's self-realisation. This understanding of solidarity is rooted in a cognition another, and the whole plenty of their personality, is man's greatest good, and that we may only find ourselves fully solely through a disinterested gift of ourselves. ${ }^{60}$ This also requires recognition of a special type of a cultural bond among people and recognition of a shared destiny and vocation. ${ }^{61}$

Solidarity is linked to subjectively conceived common good, since it means "a constant readiness to accept and realise a part of the common good that falls due to everyone by virtue of being a member of a community." ${ }^{22}$ By virtue of solidarity, man fulfils himself. Solidarity is thus the opposite of individualism and egoism. ${ }^{63}$ As the pope, Wojtyła will emphasise the ethical dimension of solidarity and define it as a "strong and permanent will of commitment for the common good" 64 that "helps to perceive another - person, people or nation - not as a tool whose ability to work or physical stamina can be used cheaply which is rejected

59 Cf. K. Wojtyła, Osoba i czyn, p. 331.

${ }^{60}$ Cf. Sobór Watykański II, Konstytucja Gaudium et spes, in: Sobór Watykański II, Konstytucje, dekrety, deklaracje, Poznań 1968, No. 24.

${ }^{61}$ Cf. R. Buttiglione, Myśl Karola Wojtyły, tłum. J. Merecki, Lublin 1996, p. 244.

62 K. Wojtyła, Osoba i czyn, p. 323.

${ }^{63}$ Cf. Ioannes Paulus PP. II, Litterae encyclicae Centesimus annus (1.05.1991), "Acta Apostolicae Sedis" [=AAS] 83 (1991), no. 49.

64 Ioannes Paulus PP. II, Litterae encyclicae Sollicitudo rei socialis (30.12.1987), AAS 80 (1988), no. 38 . 
when no longer useful, but as similar to ourselves." ${ }^{\text {"65 }}$ Thus, solidarity, in the name of care for social justice, refers to dignity of each man, including one we are in conflict with. Solidarity is thus a social virtue, a moral obligation to responsibility for one another. It is a way of existence of the human community - in a unity worthy of man. Styczen will express it as follows: "We are, all together and each of us, condemned to a radical solidarity" ${ }^{66}$

\section{Conclusion}

A greater ethico-political sensitivity to man and his dignity is a key achievement of personalism. The theory of man as a person, with its essential feature of dignity due to all people, entails the contemporary concept of democratic order. In light of the above discussion, the question is crucial, to what extent the type of democracy, a political and economic system adopted in Poland, is effective at strengthening the sense of membership in a community of persons founded on humanity. How effective is this system at protecting the transcendent nature of the person and their dignity against sometimes merciless market mechanisms and powerful capabilities of technology? Quality and form of democracy in Poland depend on answers to these questions.

Native and inalienable human dignity is the fundamental good personalism desires to protect. This dignity means above all value of a person as such due to somebody by the sole virtue they are human. The reference to dignity in the preamble to the Constitution of Poland implies it should provide the foundation and test of interpretation of all laws and regulations intended to realise human rights and freedoms under the Polish legal system. Dignity thus becomes the ultimate criterion that should be applied to any legal regulations. A person's dignity is immovable and the legislator is expected to do their best to secure and protect

65 Ioannes Paulus PP. II, Litterae encyclicae Sollicitudo rei socialis, no. 39.

66 T. Styczeń, Być soba to przekraczać siebie - O antropologii Karola Wojtyly, in: K. Wojtyła, "Osoba i czyn" oraz inne studia antropologiczne, p. 509. 
it from any actions against it. This is the fundamental thesis and postulate of personalism.

Solidarity, cited in the preamble to the Constitution, seems to be the fruit of reading not only of political developments that led Central and Eastern European countries to remove the yoke of communism in the late 1980s, but above all of reading a profoundly axiological truth about man that calls for primacy of morality in politics, without which a genuinely human social order cannot be constructed. This is an order where one in community with others is to become more human, more of a person.

\section{Bibliography}

Arystoteles, Dzieła wszystkie, t. 3, tłum. P. Siwek, Warszawa 1992.

Auleytner J., Polityka społeczna. Teoria i praktyka, Warszawa 2000.

Barth G., Hermeneutyka osoby, Lublin 2013.

Bartnik C. S., Personalizm, Lublin 2000.

Biesaga T., Godność a wolność w antropologii Karola Wojtyły, in: Ku rozumieniu godności człowieka, red. G. Hołub, P. Duchliński, Kraków 2008, pp. 65-76.

Biesaga T., Podstawy etyki i bioetyki, Kraków 2016.

Bocheński J.M., W obronie cywilizacji chrześcijańskiej, in:Polski testament. Ojczyzna, Europa, cywilizacja, Komorów 1999.

Buttiglione R., Myśl Karola Wojtyty, tłum. J. Merecki, Lublin 1996.

Chudy W., Osoba ludzka w społeczeństwie, in: Katolicka nauka społeczna. Podstawowe zagadnienia z życia społecznego i politycznego, red. S. Fel, J. Kupny, Katowice 2007, pp. 31-56.

Gilson E., Tomizm. Wprowadzenie do filozofii św. Tomasza z Akwinu, tłum. J. Rybałt, Warszawa 1998.

Ioannes Paulus PP. II, Litterae encyclicae Centesimus annus (1.05.1991), "Acta Apostolicae Sedis" 83 (1991), pp. 793-867.

Ioannes Paulus PP. II, Litterae encyclicae Sollicitudo rei socialis (30.12.1987), "Acta Apostolicae Sedis" 80 (1988), pp. 513-586.

Krąpiec M.A., Człowiek i prawo naturalne, Lublin 1986. 
Maryniarczyk A., Realistyczna interpretacja rzeczywistości, Lublin 2005 (Zeszyty z Metafizyki, 3).

Mazurek F., Godność osoby ludzkiej jako wartość absolutna, "Roczniki Nauk Społecznych" 21 (1993) z. 1, pp. 261-271.

Ossowska M., Normy moralne. Próba systematyzacji, Warszawa 1972.

Pala A., Godność - wolnosś́ - miłość: struktura dynamizmu życia osobowego człowieka w ujęciu Karola Wojtyty, "Logos i Ethos" (2019) 2, pp. 131-151.

Polak P., Trzciński J., Konstytucyjna zasada godności człowieka $w$ świetle orzecznictwa Trybunału Konstytucyjnego, "Gdańskie Studia Prawnicze" 40 (2018), pp. 257-274.

Possenti V., Osoba nowa zasadą, tłum. J. Merecki, Lublin 2013.

Reale G., Historia filozofii starożytnej, t. 2: Platon i Arystoteles, tłum. E. Zieliński, Lublin 1996.

Rodziński A., U podstaw kultury moralnej, Warszawa 1980.

Skrzydlewski P., Kolektywizm, indywidualizm a osobowa wizja człowieka, in: Spór o osobę w świetle klasycznej koncepcji człowieka. Studia i rozprawy, red. P.S. Mazur, Kraków 2012, pp. 122-176.

Sobór Watykański II, Konstytucja Gaudium et spes, in: Sobór Watykański II, Konstytucje, dekrety, deklaracje, Poznań 1968, pp. 537-620.

Spaemann R., Osoby. O różnicy między czymś a kimś, tłum. J. Merecki, Warszawa 2001.

Styczeń T., Być sobą to przekraczać siebie - O antropologii Karola Wojtyty, in: K. Wojtyła, “Osoba i czyn” oraz inne studia antropologiczne, red. T. Styczeń et al., Lublin 1994, s. 493-526.

Styczeń T., Filozoficzna koncepcja prawa naturalnego, "Analecta Cracoviensia" 1 (1969), pp. 297-320.

Styczeń T., Nienarodzony miara demokracji, w: T. Styczeń, Wprowadzenie do etyki, Lublin 1993, pp. 175-188.

Styczeń T., Objawiać osobę, w: T. Styczeń, Wprowadzenie do etyki, Lublin 1993, pp. 13-21. Styczeń T., W sprawie etyki niezależnej, w: T. Styczeń, Wprowadzenie do etyki, Lublin 1993, pp. 43-80.

Szostek A., Rola pojęcia godności w etyce, "Studia Filozoficzne" (1983) nr 8-9, pp. 77-91.

Szostek A., Wolność - prawda - sumienie, "Ethos" 4 (1991) nr 3-4 (15-16), pp. 25-37.

Tomasz z Akwinu, Suma teologiczna, t. 1-34, tłum. P. Bełch, London 1962-1986.

Wierzbicki A.M., Karola Wojtyty filozofia osoby ludzkiej jako podstawa obrony praw człowieka, w: Jan Paweł II. Postuga myślenia, red. J. Kupczak, D. Radziechowski, Kraków 2011, pp. 141-163. 
Wojtyła K., Człowiek jest osoba, in: K. Wojtyła, “Osoba i czyn” oraz inne studia antropologiczne, red. T. Styczeń et al., Lublin 1994, pp. 417-420.

Wojtyła K., Miłość i odpowiedzialność, Lublin 2001.

Wojtyła K., Osoba i czyn, in: K. Wojtyła, "Osoba i czyn” oraz inne studia antropologiczne, red. T. Styczeń et al., Lublin 1994, pp. 51-344.

Wojtyła W., Transcendencja i uczestnictwo jako klucz do zrozumienia osoby. Przyczynek do antropologii Karola Wojtyty-Jana Pawła II, 33 (2020) nr 1 (129), pp. 365-382.

Wroceński J., Godność osoby ludzkiej podstawa prawa do wolności religijnej, "Prawo Kanoniczne" 59 (2016) nr 3, pp. 3-18.

Zieliński S., Rozumienie godności człowieka i jej znaczenie w procesie stanowienia i stosowania prawa. Propozycja testu zgodności i regulacji prawnych z zasada godności człowieka, "Przegląd Sejmowy" 27 (2019) nr 4 (153), pp. 107-127.

Zoll A., Czy demokracja pomaga w stanowieniu prawego prawa?, w: Sacrum i kultura. Chrześcijańskie korzenie przyszłości, Lublin 15-17 IX 2000, red. R. Rubinkiewicz, S. Zięba, Lublin 2000, pp. 59-72.

\section{Abstract}

\section{Personalist Foundations of the Constitutional Principle of the Dignity of Human Person}

Placing the concept of human dignity in the preamble to the Constitution of the Republic of Poland reaffirms it as the foundation of the entire legal system in the state, where it has the status of a value determining application of all norms. Defining sense of human dignity and uncovering its sources is the goal not of the legal doctrine, however, but of philosophy. This paper is an attempt at answering the question, what reality is the person's dignity from the viewpoint of personalism and what constitutes it. Answering this question is crucial to the process of law institution and application.

\section{Keywords}

personal being, subjectivity, participation 


\section{Abstrakt}

\section{Personalistyczne podstawy konstytucyjnej zasady godności osoby ludzkiej}

Umieszczenie pojęcia godności człowieka w preambule Konstytucji Rzeczpospolitej Polskiej potwierdza, że stanowi ona podstawę całego porządku prawnego w państwie. W systemie prawnym państwa posiada ona status wartości określającej stosowanie wszystkich norm. Określenie sensu pojęcia ludzkiej godności i odsłanianie jej źródeł należy jednak nie do doktryny prawnej, lecz do filozofii. Artykuł podejmuje próbę odpowiedzi na pytanie, jaką rzeczywistością z punktu widzenia personalizmu jest godność osoby i co o niej stanowi. Odpowiedź na to pytanie ma kluczowe znaczenie w procesie stanowienia i stosowania prawa.

\section{Słowa kluczowe}

byt osobowy, podmiotowość, uczestnictwo 